\title{
Fortellinger som blodtrykksbehandling
}

\section{A se filmer der andre hypertoni- pasienter forteller sine historier, kan øke effekten av vanlig blodtrykks- behandling.}

Mange pasienter med hypertoni oppnår ikke ønskede blodtrykksverdier på behandling foreskrevet av lege. Lav etterlevelse er særlig vanlig blant pasienter med lav inntekt og lite utdanning.

I en studie i USA ble 299 fargede hypertonipasienter med lav sosial status randomisert til en intervensjonsgruppe og en kontrollgruppe. Intervensjonsgruppen fikk utdelt tre DVD-filmer og ellers fulgt opp på vanlig måte (1). Filmene var basert på intervjuer med personer med hypertoni fra den aktuelle studiepopulasjonen og inneholdt også fakta om blodtrykk og råd om sunn livsstil. Kontrollgruppen fikk DVD-filmer med helseinformasjon uten direkte relevans for hypertoni samt vanlig oppfølging.

230 pasienter $(77 \%)$ fullførte studien. Hos dem som hadde ukontrollert hypertoni ved studiestart, var blodtrykket lavest blant dem som fikk se intervjufilmene, både etter tre måneder og ved studieslutt etter 6-9 måneder. Det var ingen forskjell mellom pasienter med kontrollert blodtrykk ved studiestart.

- Studien åpner for interessante perspektiver, selv om den har mange svakheter og begrensninger, sier Jan Frich ved Universitetet i Oslo, som har interessert seg mye for narrativ medisin, altså bruken av fortellinger i terapeutisk sammenheng. Nærliggende forklaringer for effekten på blodtrykk er at pasientene identifiserte seg med intervjuobjektene i filmene, fikk økt tiltro til betydningen av livsstilsendringer og ble motivert til å følge foreskrevet behandling.

Det er usikkert om erfaringene kan overføres til andre grupper av pasienter. Studien viser likevel at rollemodeller, ofte omtalt som likemenn, kan ha en viktig funksjon for andre pasienter gjennom å dele sine erfaringer med å leve med kronisk sykdom, sier Frich.

\section{Petter Gjersvik}

petjense@online.no

Tidsskriftet

\section{Litteratur}

1. Houston TK, Allison JJ, Sussman M et al. Culturally appropriate storytelling to improve blood pressure. A randomized trial. Ann Intern Med 2011; 154: $77-84$

\section{Paricalcitol nedsetter albuminuri ved diabetisk nefropati}

Pasienter med diabetes mellitus har økt risiko for progredierende nyresvikt med albuminuri til tross for behandling med hemmere av renin-angiotensin-systemet. Nå viser en ny studie at forekomsten av albuminuri kan reduseres ved å bruke paricalcitol i tillegg til renin-angiotensin-hemmere (Lancet 2010; 376: 1543-51).

Multisenterstudien var placebokontrollert, randomisert og dobbeltblindet og varte i 24 uker. Den omfattet 281 pasienter med type 2-diabetes og albuminuri.

De som fikk $2 \mu \mathrm{g}$ paricalcitol hadde en hurtig innsettende, vedvarende reduksjon i urin-albumin-kreatinin-ratio på 18-28\% $(p=0,014)$ sammenliknet med dem som fikk placebo.

\section{For mange ICD-10-koder i psykiatrien?}

I den danske versjonen av ICD-10-koder for psykiatriske og atferdsmessige lidelser er det 389 forskjellige diagnoser, men mange av dem brukes svært sjelden, ifølge en ny studie (World Psychiatry 2010; 9: 183-4).

Halvparten av alle 1,2 millioner psykiatriske diagnoser faller innenfor en gruppe på 16 diagnoser, skriver forfatterne, som har analysert alle diagnoser i det danske psykiatriske forskningsregisteret i perioden 2001 -07. 50-prosentilen $(50,1 \%)$ ble nådd ved 16 diagnoser $(4,2 \%$ av de 389 mulige diagnoser).

De tre hyppigst registrerte diagnosene var paranoid schizofreni, alkoholavhengighet og tilpasningsreaksjon.

\section{Ny kunnskap om mekanisme som fører til depresjon}

\section{Oppregulering av MKP-1 i hippocam- pus ser ut til å ha betydning for utvik- ling av depresjon.}

De molekylære mekanismene for utvikling av depresjon er i stor grad ukjente. En amerikansk forskergruppe har nå gjort helgenomekspresjonsanalyse av hippocampusvev tatt postmortem fra 21 individer med depresjon og 18 kontrollpersoner uten depresjon (1). Forskerne identifiserte $M K P-1$ som signifikant oppregulert i hippocampusregioner hos deprimerte individer, både på RNA og på proteinnivå. MKP-1 er et protein som defosforylerer både treonin og tyrosin, og er således en negativ regulator av mitogenaktivert proteinkinase (MAPK)-kaskaden, som er essensiell for hjernens funksjon.

Forskerne utførte også dyrestudier, og fant at mus uten $M K P$-1-genet var beskyttet mot utvikling av depresjon etter stress. Rotter som i modellsystemer med virusmediert genoverføring fikk overuttrykk av genet, utviklet symptomer på depresjon.

- Styrken ved denne studien ligger nettopp $i$ at de har kombinert data fra mennesker og eksperimentelle studier hos dyremodeller, sier professor Jan Haavik ved Institutt for biomedisin, Universitetet i Bergen. Ettersom det finnes flere hundre ulike proteinkinaser

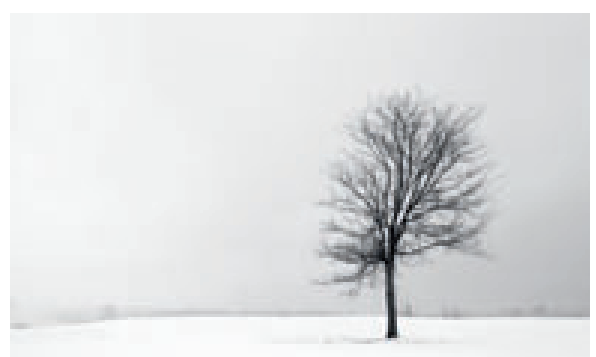

Illustrasjonsfoto Istockphoto

og fosfataser i menneskehjernen, og proteinfosforylering er involvert i de fleste cellulære prosesser, er det ikke overraskende at man kan påvise endringer i disse signalveiene ved depresjon. Innenfor andre terapiområder er det utviklet og tatt i bruk hemmere av proteinkinaser og fosfataser, men det er for tidlig å konkludere om slike medikamenter også vil få noe plass i behandlingen av depresjon hos mennesker, sier Haavik.

\section{Åslaug Helland \\ aslaug.helland@gmail.com \\ Tidsskriftet}

\section{Litteratur}

1. Duric V, Banasr M, Licznerski $P$ et al. A negative regulator of MAP kinase causes depressive behaviour. Nat Med 2010; 16: 1328-32. 